\title{
Rape embryogenesis. VI. Formation of protein bodies
}

\author{
TERESA TYKARSKA
}

\author{
Laboratory of Electron Microscopy, Institute of Botany, Warsaw University, \\ Krakowskie Przedmieście 26/28, 00-927 Warsaw, Poland \\ (Received: November 21, 1986. Revision accepted: May 25, 1987)
}

\begin{abstract}
The storage protein synthesis starts in Brassica napus var. Górczański embryo at the final embryogenesis stage, i.e. in green seeds. Storage protein accumulate in selected zones adjacent to big vacuoles. These vacuoles, as well as surrounding protein zones, are subject to fragmentation. Young aleuron grains originate. They grow occupying sites of declining vacuoles. In mature rape embryo two kinds of protein bodies occur: aleuron grains, well-stainable with protein-specific dyes, and myrosin grains weakly-stainable with them but PAS-positive. Myrosin grains occur earlier than aleuron grains in special cortex and cytoledon cells. Although the first aleuron grains form in outer cells of lateral cap parts and in cortex cells at the hypocotyl-root boundary, they originate most rapidly in endodermis. In the embryo axis aleuron grains form so rapidly that at the beginning of browning of the seed coat most of them are already formed. Aleuron grains developed in all embryo cells accept in those of the youngest columella layers and differentiated procambial strands. The accumulation of storage protein lasts till the end of seed maturation.
\end{abstract}

Key words: rape embryogenesis, storage material, protein bodies

\section{INTRODUCTION}

Protein bodies are commonly known storage reserves occuring mainly in seeds. In rape both lipid and protein bodies form storage material. Their distribution in mature embryo has been already studied by Kuraś (1984). He has presented their hystological diversity in single organs and within cells. The origin and transformation of lipid bodies in developing embryo have been presented in the previous paper from the "Rape embryogenesis" series 
(Tykarska 1987). The formation of the first aggregates of storage protein and their transformation into aleuron grains with a large number of globoids in the rape embryogenesis have been studied by Kavetskaya (1960). Rest and Vaughan (1972) have distinguished two kinds of protein bodies in Sinapis alba (a species closely related to rape). These are: aleuron grains occuring in most embryo cells, and myrosin grains forming only in few myrosin idioblasts. The latter are homogeneous and develop earlier. They easily stain with dyes nonspecific to protein and are Schiff-positive (Goding et al. 1970). Myrosin cells are scattered over cytoledon parenchyma and embryo cortex (Guignard 1890). Iversen et al. (1979) have analysed the distribution of myrosin cells in germinating Brassicaceae seeds.

According to Crouch and Sussex (1981) main storage protein are not recognized in the first phase of rape embryo growth when cell divisions take place and embryo organs form. They occur in the second seed developmental phase and rapidly accumulate with the increase in embryo dry mass (Norton and Harris 1975, Crouch and Sussex 1981).

The present paper is a continuation of studies on starch (Tykarska 1982) and lipid (Tykarska 1987) accumulation in rape embryo. Also developmental changes in the embryo axis during formation of protein bodies have been taken into account. The studies are concerned with final embryogenesis stages, from green to black seeds.

\section{MATERIAL AND METHODS}

Cotyledon-less embryo axes or whole embryos were prepared out of rape (var. Górczański) seeds during last mitoses and at the successive maturation stages. They were fixed in 10\% acrolein, 0.1-10 uranyl-acrolein and 0.25-0.5-10 CrAF (chrom-acet-formalin). Parafin sections were stained with protein-specific dyes like: fast green in citrate-phosphate or phosphate $(\mathrm{pH} 3-8)$ buffers (Alfert and Geschwint 1953), brom-phenol blue (mercuric brom-phenol blue according to Mazia et al. 1953), acid fuchsin (Gerlach 1969) and by PAS method.

$1 \mathrm{~mm}$ embryo axis apices were fixed in $2 \%$ glutaraldehyde and next in $1 \%$ osm and embedded in epon. Semi-thin sections were stained with toluidine blue.

\section{RESULTS}

EMBRYOGENESIS TERMINATION

Embryo is finally developed. It has large cotyledons, six-layered columella and leaf primordium. However, it is smaller than a mature one and loosely fits to the seed coat. Both embryo and seed coat are bright green. At this 
stage the last mitoses take place in the embryo, while starch and lipid bodies rapidly accumulate (Tykarska 1982, 1987).

From the present studies it may be inferred that just in this time the formation of protein bodies occurs. First, myrosin grains form (Fig. 1). They are spherical, homogeneous, stainable by PAS method and slightly stained with fast green and brom-phenol blue. They originate in special cells of primary cortex and cotyledons. These cells are usually bigger than their surrounding cells. In hypocotyl the myrosin cells resemble their neighbours; in root they are oval (Fig. 15), scarce, usualy 6-8 in a single central axis section.

When myrosin grains are visible, the cytoplasm of embryo cortex cells becomes slightly stainable with fast green, brom-phenol blue, and acid fuchsin. Soon, in the embryo axis two areas with strongly staining cells differentiate: cortex of lower hypocotyl and root top, as well as outer layers of lateral cap parts (Fig. 6). Storage protein accumulated in aleuron grains is responsible for the staining. At the same time in slightly stained cortex cells of the upper hypocotyl aleuron grains start to form. Thus, around large vacuoles slightly stained areas appear that are disti ict from colourless vacuoles and cytoplasm (Fig. 2). The areas extend in time and their affinity to protein dyes increases.

\section{SEED MATURATION}

Early green seeds ("green a" Tykarska 1980)

Seeds are green and fairly hard. Although embryos are more massive than at the previous stage, they still loosely fit to the seed coat.

In embryo cortex cells storage protein still rapidly accumulates. The accumulation areas surround large vacuoles. In a densening substance light patches-forming globoids, are still better visible (Fig. 3). The both large vacuoles and neighbouring storage protein zones undergo fragmentation (Fig. 4). Young aleuron grains form (Fig. 5). They gradually fill up with protein and grow replacing now declining vacuoles.

Aleuron grains first originate in lateral cap parts, lower hypocotyl cortex at its boundary with root, as well as in endodermis (the quickest) and pericycle (Fig. 8). Later the process extends along and across nearly whole embryo axis. Figure 17 illustrates the directions of aleuron grain formation.

In cotyledons protein bodies originate later than in the embryo axis. At this stage they occur only in the outer cotyledon. In the inner cotyledon cytoplasm is so lightly stained that any changes are difficult to observe.

Protein bodies form quicker at the inner side of embryo curve.

Late green seeds ("green b" Tykarska 1980)

Green seeds are hard. Their colour becomes dimmer and gets brown. Massive embryo is tightly covered with seed coat and difficult to prepare 
PLATE

Formation of protein bodies. Fig. 1. Cortex fragment of upper hypocotyl from the embryo at the initial phase of protein formation, stained with fast green at $\mathrm{pH} 7.8$ and by PAS, $\times 700$. In myrosin cell strongly stained myrosin grains, elsewhere only starch is stained. Fig. 2. Enlarged fragment of embryo cortex from Fig. 6 (in a frame) in the initial phase of aleuron grain formation: storage protein accumulation zones are distinct from the background of light vacuoles, $\times 1500$. Fig. 3 . Cortex cell with forming aleuron grains. In protein accumulation zones small, light patches, i.e. globoids, are visible, $\times 1250$. Fig. 4. Simultaneous fragmentation of vacuoles and storage protein accumulation zones, $\times 1500$. Fig. 5. Young aleuron grains, light vacuoles still visible, $\times 1250$. Figs. $2-5-$ stained with fast green

\section{PLATE II}

Embryo axes at the formation of aleuron grains, fixed in $10 \%$ acrolein, $\times 80$. Fig. 6 . Termination of embryogenesis. Storage protein start to accumulate. In outer cap layers, and in periblem at hypocotyl-root boundary dark cells visible. Stained with fast green at $\mathrm{pH} 4$ (framed fragment presented in Fig. 2). Fig. 7. Begining of embryo maturation (green seed). Young aleuron grains are already present in dark-coloured periblem and plerom cells. Some very dark cortex cells, especially in subepidermis, are myrosin cells. Stained with fast green at $\mathrm{pH} 8$

PLATE III

Seed maturation. Fig. 8. Early green seed. Fragment of central cylinder and primary cortex from the central part of hypocotyl. Protein bodies visible in endodermis cells. Fixed in $\mathrm{CrAF}$, stained with brom-phenol blue, $\times 1500$. Fig. 9. Cortex and epidermis fragment from late green seeds, fixed in GA, stained by PAS. In myrosin cell large, dark-coloured myrosin grains. In the whole section starch grains are more strongly stained. In other cells slightly coloured aleuron grains are visible. Fig. 10. Root apex from late green seeds. Protein bodies already formed in outer columella layer. Fixed in $10 \%$ acrolein, stained with fast green at pH 7.4, $\times 500$. Fig. 11. Brown seeds. Fragment of hypocotyl-root boundary. Large protein bodies in subepidermis, tiny - in epidermis. Fixed in $10 \%$ acrolein, stained with fast green

$$
\text { at } \mathrm{pH} 4, \times 1500
$$

\section{PLATE IV}

Protein bodies in black seeds. Fig. 12. Shoot apex. Aleuron grains in all meristematic cells. Fixed in $10 \%$ acrolein, stained with fast green at $\mathrm{pH} 3.6, \times 700$. Fig. 13. Procambium fragment in a strand entering in cotyledons. No protein bodies in metaxylem cells. Fixed in 0.1-10 $\mathrm{AU}$, stained with fast green at $\mathrm{pH} 8, \times 1500$. Fig. 14. Epidermis and subepidermis fragment in upper hypocotyl. Fixed in UA, stained with acid fuchsin, $\times 1500$. Fig. 15 . Periblem fragment in upper root part. Myrosin cell surrounded by aleuron cells. Fixed in $\mathrm{GA}+\mathrm{OsO}_{4}, \times 1500$. Fig. 16. Central cylinder and primary cortex in upper embryo

part. Fixed in UA, stained with acid fuchsin, $\times 1500$

out. Its root is whitish, hypocotyl light green while cotyledons bright green.

Dense aleuron bodies with distinct globoids are almost in the whole embryo (Fig. 7). They are absent in the shoot apical meristem, inner cotyledon, some epidermis cells of lower hypocotyl, inner cells of lower central cylinder, outer cortex of root apex and in inner columella layers (Figs. 10, 18). 
PLATE I

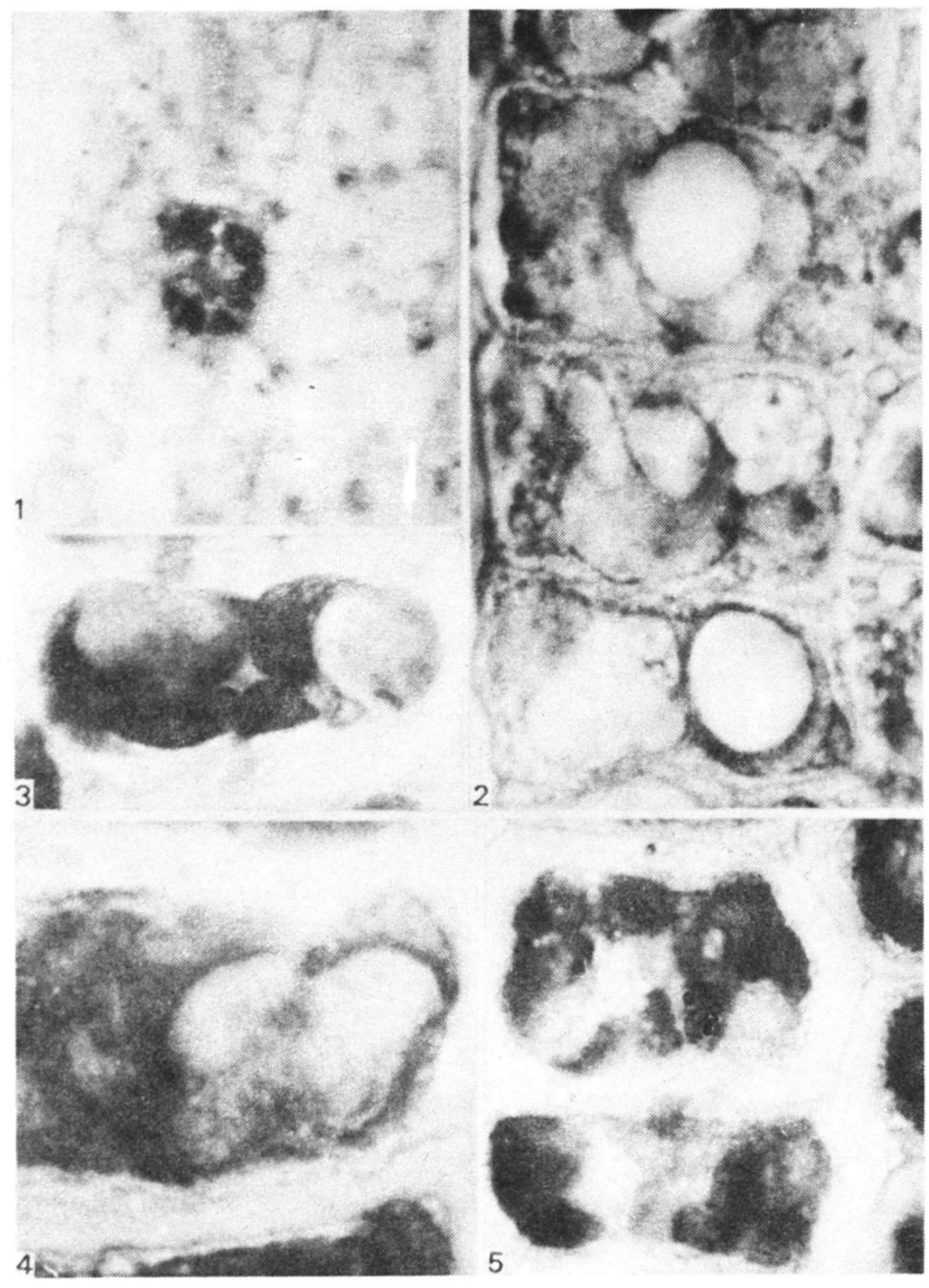


PLATE II

6

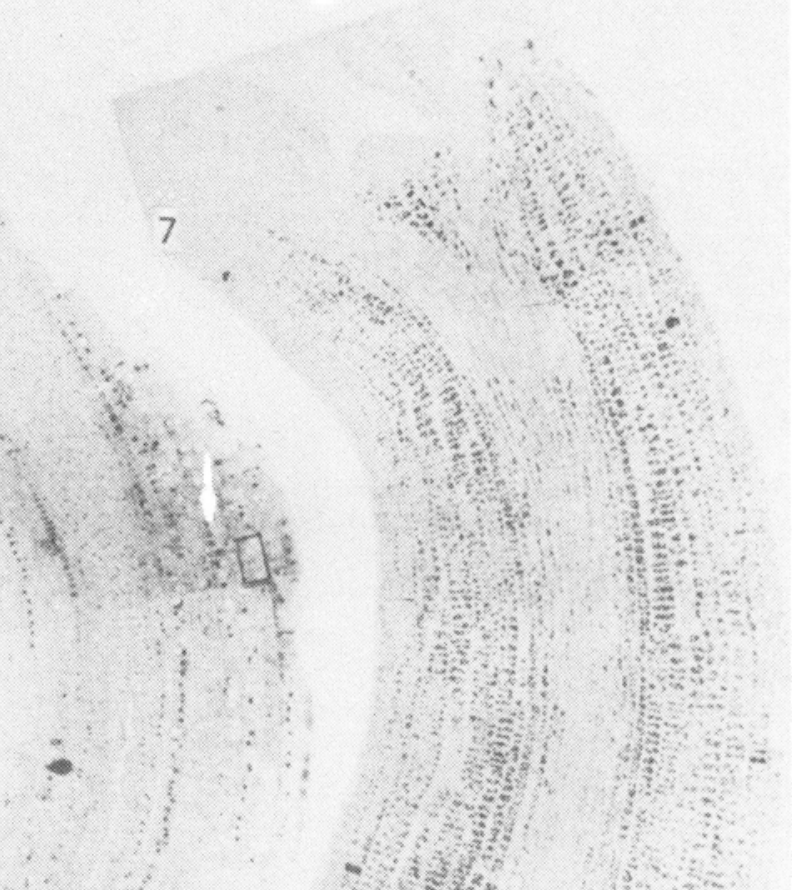

*. $x^{2}-x^{2} x^{2}$

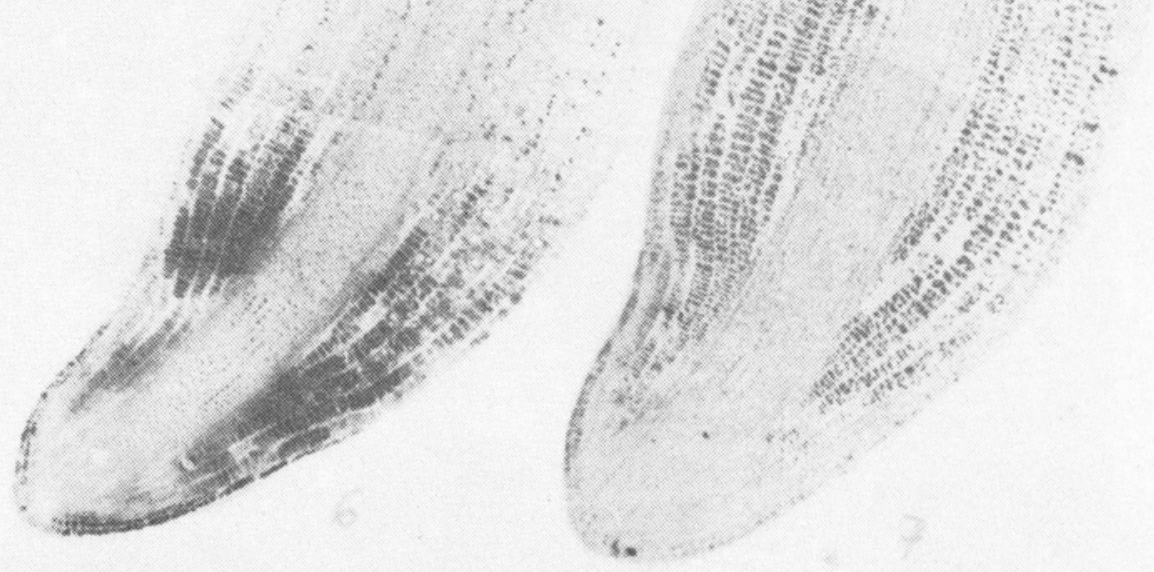


PLATE III

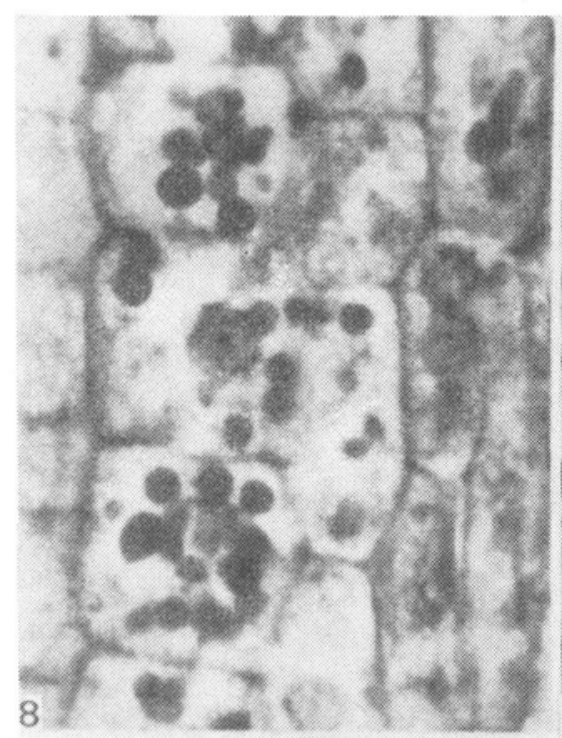

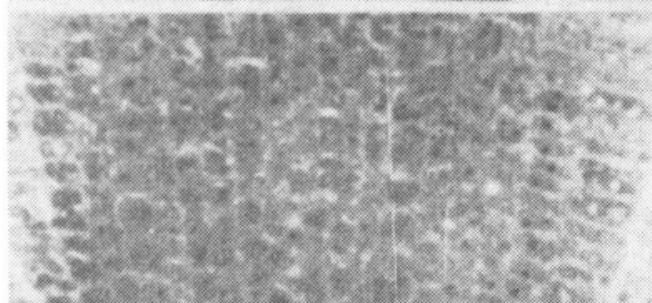
(2.

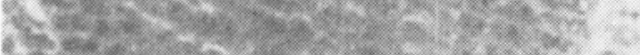

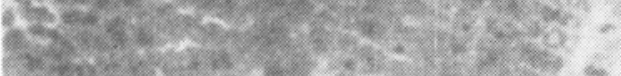

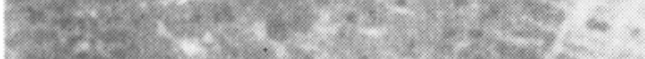

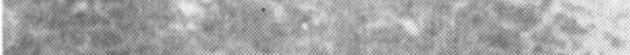

S.

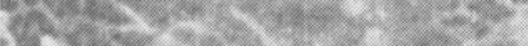

S.

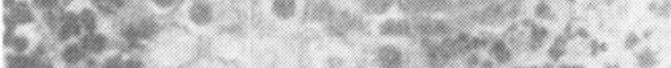

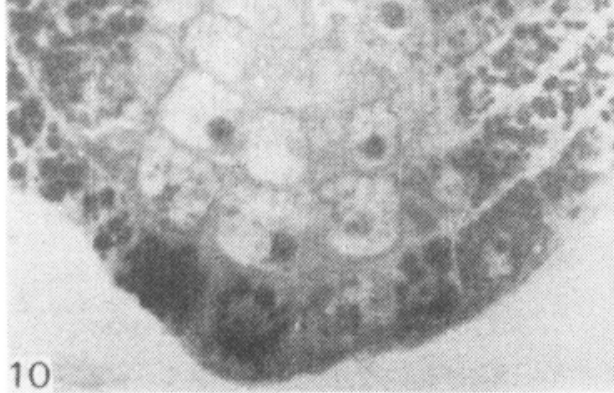

(4)
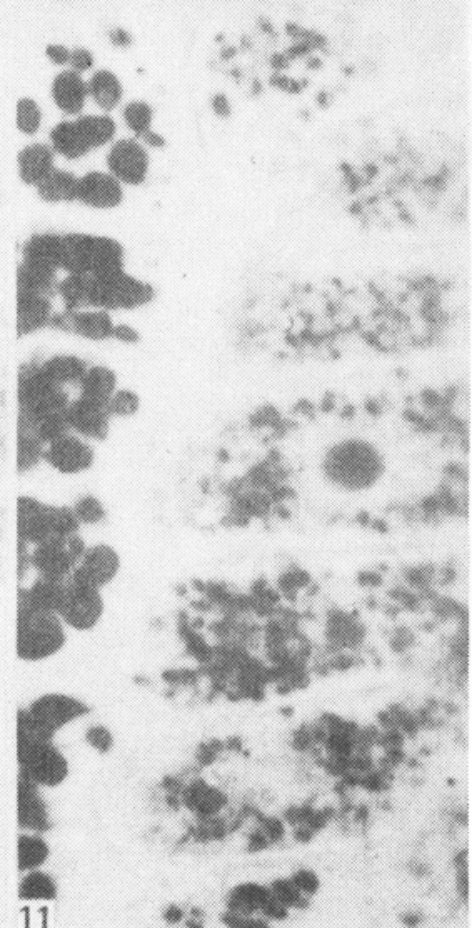

(1.)
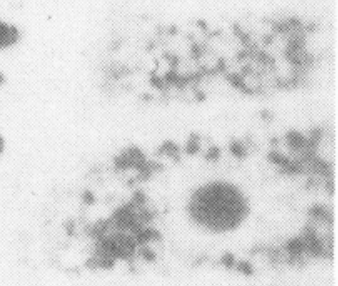

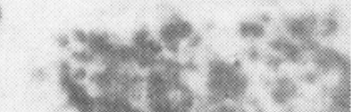

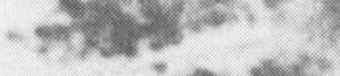

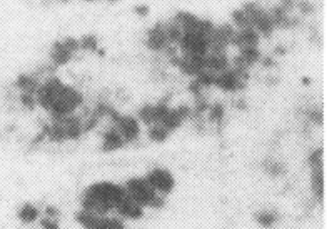

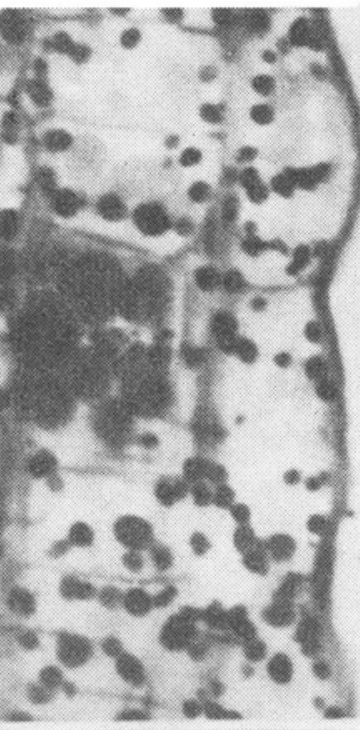

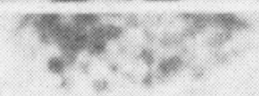


PLATE IV

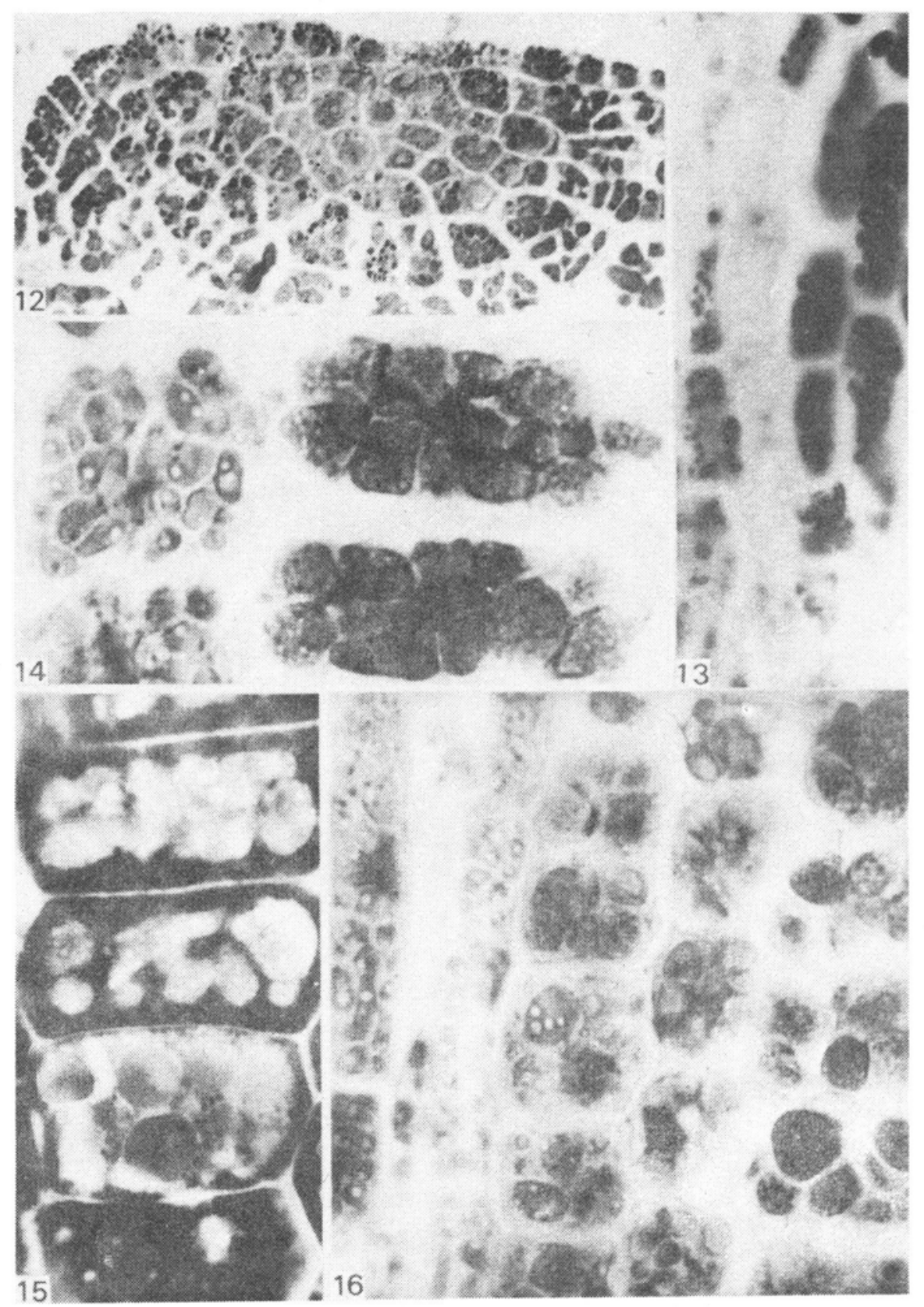



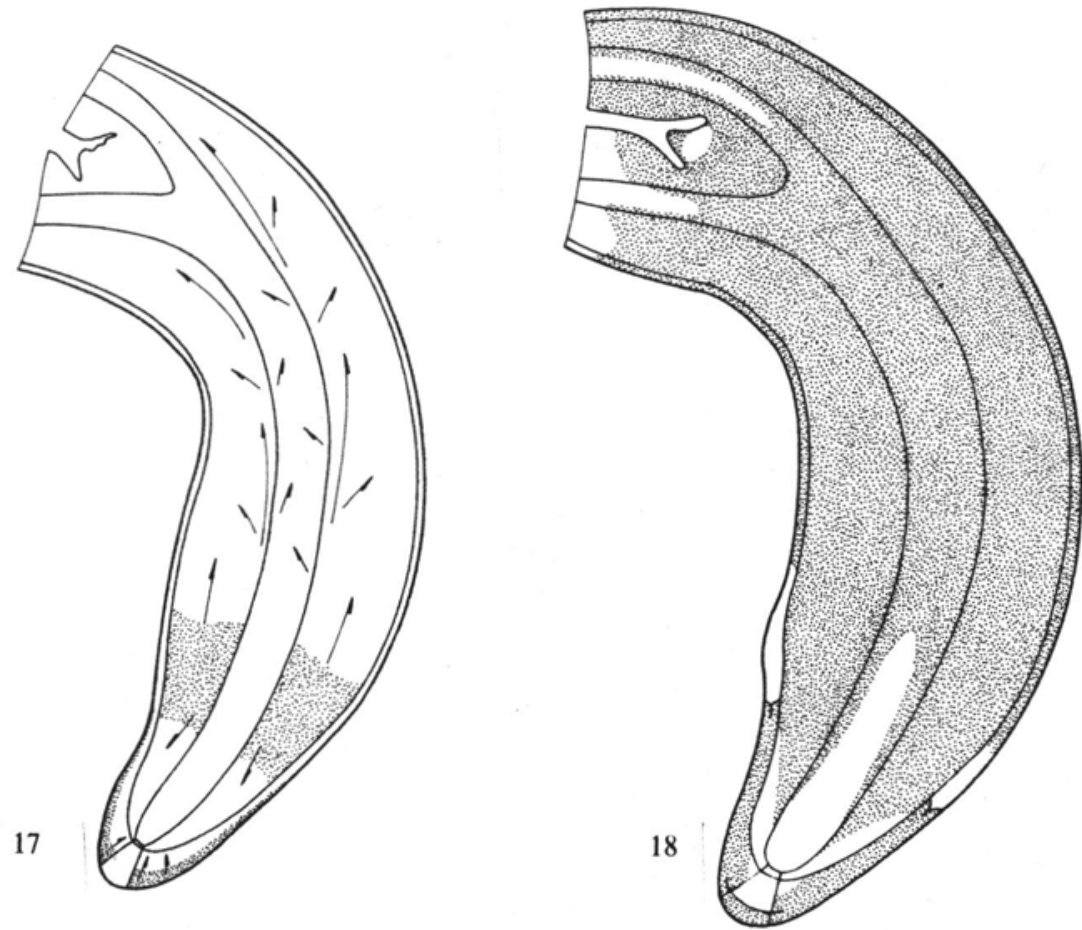

Fig. 17. Formation of aleuron grains in rape seeds. Dots indicate zones of first aleuron grain formation. Arrows show directions of aleuron grain formation in other embryo axis parts

Fig. 18. Embryo axis from late green seeds. Dots indicate areas with already formed protein bodies

From this stage in cortex sections cytoplasm stops to stain first at the outer side of embryo curve, while aleuron grains are well stainable there. Cytoplasm stains well merely in cells devoid of aleuron grains.

\section{Green-brown seeds}

Embryo axis whitish, cotyledons light green. Only shoot apical meristem, apical root part, inner columella layers, and epidermis at the hypocotyl-root boundary lack aleuron grains. Except those of columella, the cytoplasm of these cells is well stained.

Globoids are not evenly distributed inside aleuron grains. Aleuron grains in hypocotyl periblem contain most globoids, those of central cylinder and epidermis (Figs. 14, 16) - much less, whereas those of columella do not have them at all. 
Brown seeds

Embryo axis whitish-creamy, outer cotyledon slightly green. In brown seed tiny aleuron grains form in epidermis at the hypocotyl-root boundary (Fig. 11). Upper, in epidermis cells they are much bigger (Fig. 14). Also in inner cotyledon aleuron grains develop.

\section{Black seeds falling out of siliques}

Embryo axis creamy-yellowish, cotyledons slightly lighter. The last aleuron grains with clearly visible globoids form in all shoot apex cells in most embryos (Fig. 12). Sometimes they may also develop in root apex promeristems. Small, homogeneous grains can be observed in cells of II-III layers of columella. However they are never visible in the youngest layers, as well as in procambium strands which enter into cotyledons (Fig. 13).

Three staining methods used i.e. with brom-phenol blue, with fast green at variable $\mathrm{pH}(3-8)$, and with acid fuchsin provide the same results. Sometimes, especially during formation of protein bodies, myrosin grains stain better than aleuron grains (Fig. 7). In material fixed in aldehydes and stained by PAS method aleuron grains are pinkish (Fig. 9).

\section{DISCUSSION}

Protein bodies occur when cell divisions terminate. Their formation takes place very fast. These results are comparable with those by Crouch and Sussex (1981). At the initial stages of embryo maturation most protein bodies are already formed. Only in shoot and root apices they are still absent.

The studies show that in rape, as in other Cruciferae, two kinds of protein bodies are formed: aleuron grains - in most embryo cells, and myrosin grains - in a few idioblasts. The latter form earlier, as in the case of Sinapis (Rest and Vaughan 1972).

Aleuron grains are well stainable with fast green in a wide $\mathrm{pH}$ range, with mercuric brom-phenol blue and with acid fuchsin. Myrosin grains stain weaker with these dyes but they have, as in the case of Brassica campestris (Stanley et al. 1976), positive PAS reaction, which means they contain protein and carbohydrates.

From Aschton's (1976) studies it may be inferred that most storage proteins in plants (except in grasses) are globulins. Goding et al. (1970) have found that globulin $12 \mathrm{~S}$, glycoprotein with positive PAS reaction, is one of the main $(50 \%)$ rape soluble proteins. If it is true, a question arises: why scarce myrosin grains, and not aleuron grains, are PAS-positive? The question has been asked by Stanley et al. (1976) in their studies on the microstructure of Brassica campestris seeds. 
The studies of Crouch and Sussex (1981) indicate that glycoprotein 12S accumulates simultaneously with an increase in embryo dry mass till the seeds are mature. During this time the formation of still new aleuron grains is observed (the present studies). Pearse (1957) has stated that proteins stain by PAS method only when they contain more than $1 \%$ of carbohydrates. Thus it may be concluded that myrosin grains contain more carbohydrate components than glycoprotein $12 \mathrm{~S}$ - in all probability a component of aleuron grains. However this problem requires further elucidation.

Protein bodies are formed differently in various plants. Many authors have found that protein accumulate in small vacuoles originated from a large vacuole by fragmentation (Dangeard (1921) - in Ricinus communis, Rest and Vaughan (1972) - in Sinapis alba, Adams et al. (1985) - in Glycine $\max$ ). From the present studies it has been found that in rape hypocotyl cortex cells protein originate in special, close to central vacoule, zones. In densening storage protein globoids become visible. Shortly, still in green seeds, vacuoles with protein accumulation zones undergo fragmentation. Young aleuron grains form and grow w'ille vacuoles decline. It might be possible that the areas with storage prote $\mathrm{n}$ accumulation constitute protein vacuole that originated from endoplasmic reticulum. This requires further ultrastructural analyses.

In rape embryo some tendency in distribution of aleuron grains may be observed. First they occur in cap lateral parts and in lower hypocotyl cortex cells at its boundary with the root. Their formation is the quickest in endodermis. It is from these areas that the formation process of aleuron grains expands along, from the hypocotyl-root boundary to cotyledons and root apex, and across embryo axis, from endodermis inwards and out-wards.

Hence the structure of endodermis at the hypocotyl-root boundary has to be considered. Maybe specific, meristematic structure of dermatogen cells at hypocotyl-root boundary constitutes a special zone through which nutrients flowing from outside enter (at the formation of first protein bodies there is still the residue of endosperm in an ovule). Moreover, rapid metabolic transformations may be stimulated by already green cotyledons.

From these series of studies it may be concluded that in the embryo axis two activity zones of storage material synthesis differentiate: primary cortex at the hypocotyl-root boundary here large starch grains occur the first and exist the longest; here also the first aleuron grains are formed and columella (the biggest starch grains throughout embryo development exist and only a few lipid bodies and usually no, except outer layer, protein bodies are found). These are also the zones where rape embryo cell activation takes place during seed germination (Kuraś 1986). 


\section{REFERENCES .}

Adams C. A.. Shong Wan Norby. Rinne R. W., 1985. Production of multiple vacuoles as an early event in the ontogeny of protein bodies in developing soybean seeds. Crop Science 25: 255-262.

Alfert M., Geschwind I. I., 1953. A selective staining method for nuclei. Proc. Nat. Acad. Sci. Wash. 39: 991.

Ashton F. M., 1976. Mobilization of storage proteins of seeds. Ann. Rev. Plant Physiol. 27: 95-117.

Crouch M. L., Sussex I. M., 1981. Development and storage-protein synthesis in Brassica napus $\mathrm{L}$. embryos in vivo and in vitro. Planta 153: 64-74.

Dangeard P., 1921. Sur la formation des grains d'aleurone dans l'albumen du ricin. C. R. Acad. Sci. 173: 857-859.

Gerlach D., 1969. Botanische Mikrotechnik. Eine Einfuhrung. Georg Thieme Verlag, Stuttgart.

Goding L. A., Bhatty R. S., Finlayson A. J., 1970. The characterization of the 12S "globulin" from rapeseed and its glycoprotein component. Can. J. Biochem. 48: 1096-1102.

Guignard L., 1980. Sur la localisation des principes qui fournissent les essences sulfurees des Cruciferes. C. R. Acad. Sci. 111: 249-252.

Iversen T. H., Baggerud C., Beisvaag T., 1979. Myrosin cells in Brassicaceae roots. Z. Pflanzenphysiol. 94: 143-154.

Kavetskaya J. O., 1960. Embriologiya rapsa i dinamika nakopleniya zapasnykh vieshchestv v siemieni. Nauchn. Trudy Ukr. Acad. Seleskokh. Nauk 10: 111-119.

Kuraś M., 1984. Activation of embryo during rape (Brassica napus L.) seed germination. III. Ultrastructure of dry embryo axis. Acta Soc. Bot. Pol. 53: 171-186.

Kuraś M., 1986. Activation of rape (Brassica napus L.) embryo during seed germination. IV. Germinating embryo. The first zones of mitoses, starch and DNA synthesis and their expansion pattern. Acta Soc. Bot. Pol. 55: 539-563.

Mazia D., Brewer P. A., Alfert M., 1953. The cytochemical staining and measurement of protein with mercuric bromphenol blue. Biol. Bull. 104: 57.

Norton G., Harris J. F., 1975. Compositional changes in developing rape seed (Brassica napus L.). Planta 123: 163-174.

Pearse A. G. E., 1957. Histochemia teoretyczna i stosowana. PZWL, Warszawa.

Rest J. A., Vaughan J. G., 1972. The development of protein and oil bodies in the seed of Sinapis alba L., Planta 105: 245-262.

Stanley D. W., Gill T. A., deMan J. M., Tung M. A., 1976. Microstructure of rapeseed. Can. Inst. Food Sci. Technol. J. 2: 54-60.

Tykarska T., 1980. Rape embryogenesis. III. Embryo development in time. Acta Soc. Bot. Pol. 49: 369-385.

Tykarska T., 1982. Rape embryogenesis. IV. Appearance and disappearance of starch during embryo development. Acta Soc. Bot. Pol. 51: 381-387.

Tykarska T., 1987. Rape embryogenesis. V. Accumulation of lipid bodies. Acta Soc. Bot Pol. 56: 573-581.

\section{Embriogeneza rzepaku. VI. Tworzenie cial bialkowych}

\section{Streszczenie}

Synteza białek zapasowych w zarodku Brassica napus var. Górczański rozpoczyna się w końcowym etapie embriogenezy, w zielonych nasionach. Białko zapasowe gromadzi się w wydzielonych strefach, przelegających do dużych wakuoli. Wakuole te i otaczające je 
strefy białkowe ulegają fragmentacji. Powstają młode ziarna aleuronowe, które rosną, zajmując miejsce zanikających wakuoli. W dojrzałym zarodku rzepaku są dwa rodzaje ciał białkowych: ziarna aleuronowe, barwiące się intensywnie barwnikami specyficznymi dla białek i zwykle słabo barwiące się nimi ziarna myrozynowe, dające pozytywną reakcję PAS. Ziarna myrozynowe tworzą się przed ziarnami aleuronowymi w nielicznych, specjalnych komórkach kory i liścieni. Pierwsze ziarna aleuronowe pojawiają się w zewnętrznych komórkach bocznych części czapeczki i w komórkach kory na pograniczu hypokotyla i korzenia, ale najszybciej formują się w endodermie. Ziarna aleuronowe w osi zarodka powstają bardzo szybko, tak, że w początkach brązowienia łupiny nasiennej większość ciał białkowych jest już wykształcona. Ziarna aleuronowe tworzą się we wszystkich komórkach zarodka, prócz najmłodszych warstw kolumelli i wyróżnicowanych pasm pramiazgi. Akumulacja białek zapasowych trwa do końca dojrzewania nasion. 